\title{
THE REASSESSMENT OF THE THREATENED STATUS OF THE INDIAN ENDEMIC KOLAR LEAF-NOSED BAT HIPPOSIDEROS HYPOPHYLLUS KOCK \& BHAT, 1994 (MAMMALIA: CHIROPTERA: HIPPOSIDERIDAE)
}

\author{
Bhargavi Srinivasulu ${ }^{1}$, C. Srinivasulu ${ }^{2}$, Harpreet Kaur ${ }^{3}$, Tariq A. Shah ${ }^{4}$, G. Devender ${ }^{5}$ \& \\ Aditya Srinivasulu ${ }^{6}$
}

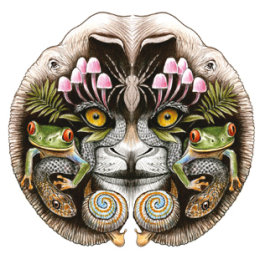

ISSN 0974-7907 (Online) ISSN 0974-7893 (Print)

OPEN ACCESS

\footnotetext{
1,2,3,4,5 Natural History Museum \& Wildlife Biology and Taxonomy Lab, Department of Zoology, University College of Science, Osmania University, Hyderabad, Telangana 500007, India

1,2 Systematics, Ecology \& Conservation Laboratory, Zoo Outreach Organization (ZOO), 96 Kumudham Nagar,

Vilankurichi Road, Coimbatore, Tamil Nadu 641035, India

1,6 Biodiversity Research and Conservation Society, 303 Orchid, Kanajiguda, Tirumalgiri, Secunderabad, Telangana 500015, India

${ }^{1}$ bharisrini@gmail.com (corresponding author), ${ }^{2}$ hyd2masawa@gmail.com, ${ }^{3}$ hkaur.ou@gmail.com,

${ }^{4}$ tariqahmed143@gmail.com, ${ }^{5}$ devenderzoo103@gmail.com, 6 juramaia98@gmail.com
}

\begin{abstract}
The Kolar Leaf-nosed Bat Hipposideros hypophyllus Kock \& Bhat, 1994, endemic to Kolar District, Karnataka, India was listed as 'Endangered' in the IUCN Red List of Threatened Species due to its restricted distribution and continuing decline in the quality of its habitat. The species has not been sighted or collected since its initial collection in the years 1983 and 1985 wherein eight individuals were collected from Therahalli and 41 individuals were collected from Hanumanhalli, respectively. Based on recent observations and collections from the type locality, we provide information about its distribution, threats, phylogenetic position and conservation status. We also provide an updated conservation assessment of this species following the IUCN Red List categories.
\end{abstract}

Keywords: Critically Endangered, Hanumanhalli, Hipposideros hypophyllus, Kolar.
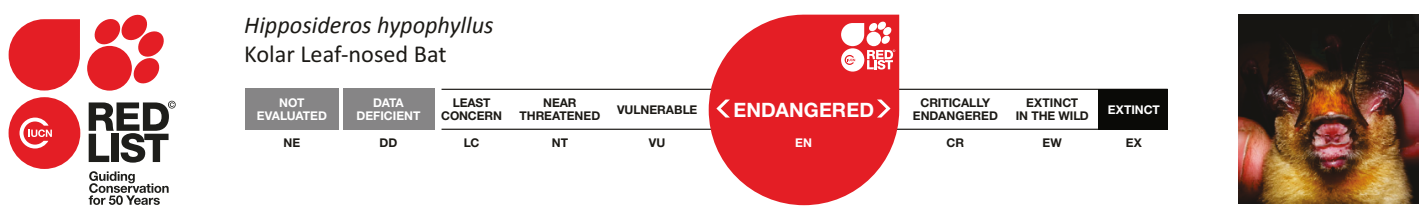

DOI: http://dx.doi.org/10.11609/JoTT.04117.6493-501 | ZooBank: urn:Isid:zoobank.org:pub:4E467CFC-FA29-4AFA-B068-C7F0E2FACBB1

Editor: Paul A. Racey, University of Aberdeen, Scotland.

Date of publication: 26 November 2014 (online \& print)

Manuscript details: Ms \# 04117 | Received 05 August 2014 | Final received 05 November 2014 | Finally accepted 11 November 2014

Citation: Srinivasulu, B., C. Srinivasulu, H. Kaur, T.A. Shah, G. Devender \& A. Srinivasulu (2014). The reassessment of the threatened status of the Indian endemic Kolar Leaf-nosed Bat Hipposideros hypophyllus Kock \& Bhat, 1994 (Mammalia: Chiroptera: Hipposideridae). Journal of Threatened Taxa 6(12): 6493-6501; http:// dx.doi.org/10.11609/JoTT.04117.6493-501

Copyright: (C) Srinivasulu et al. 2014. Creative Commons Attribution 4.0 International License. JoTT allows unrestricted use of this article in any medium, reproduction and distribution by providing adequate credit to the authors and the source of publication.

Funding: The study was funded by The Mohamed bin Zayed Species Conservation Fund (Project number 13257645) to Bhargavi Srinivasulu (BS). CS and BS thank DBT, Govt. of India (BT/PT13116/GBD/27/184/2009); CS, TAS and GD thank DST-SERB, Govt. of India (DST SB/EMEQ-239/2013); HK thanks UGC, Govt. of India (No. F.16-1784 (SC) /2010 (SA-III)) for research grants and fellowship.

Competing Interest: The authors declare no competing interests. Funding sources had no role in study design, data collection, results interpretation and manuscript writing.

For Author Details, Author Contribution and Acknowledgements see end of this article.
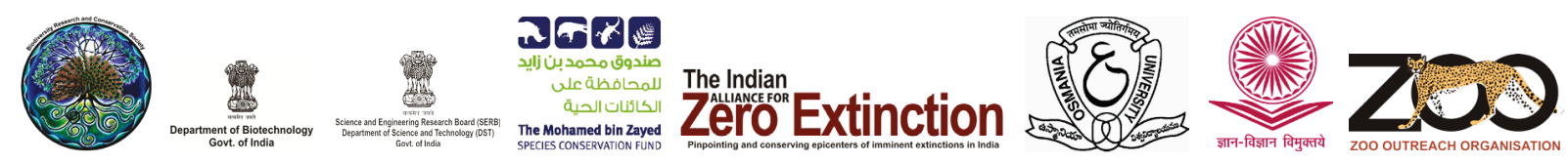


\section{INTRODUCTION}

Hipposideros hypophyllus Kock \& Bhat, 1994 belongs to the bicolor species group of the family Hipposideridae Gray, 1813 represented by 13 species in South Asia (Srinivasulu \& Srinivasulu 2012). This taxon is unique among the bicolor species group in possessing a single pair of supplementary leaflets.

From Hanumanhalli, the type locality, and Therahalli, situated about $19 \mathrm{~km}$ west of Hanumanhalli, 41 individuals and eight individuals respectively of hipposiderids of unknown identity were collected as a part of serological studies designed to investigate the role of bats in Japanese encephalitis virus transmission in the years 1983 and 1985 . These were misidentified as Hipposideros pomona based on similarities in skull morphology (Banerjee et al. 1988; Bhat \& Jacob 1990; Sreepada et al. 1993). The specimens were later reexamined and described as Hipposideros hypophyllus by D. Kock \& H.R. Bhat in 1994.

After these initial collections this species was not sighted or collected (see Molur \& Srinivasulu 2008 for further details). Hence, based on the assumption that this species is restricted to $<500 \mathrm{~km}^{2}$ and known from only two locations, this species was listed as 'Endangered' in the IUCN Red List of Threatened Species (Molur \& Srinivasulu 2008). Surveys were recommended to validate the taxonomy, distribution and the population status of the species and suggestions were made to urgently identify and protect key roosting sites of this species (Molur \& Srinivasulu 2008).

Based on recent sightings and collection of vouchers we provide updated information about the distribution, population size, threats and phylogenetic position of the species and propose an updated Red List status for this endemic species.

\section{MATERIALS AND METHODS}

\section{Study area}

Kolar District is located in south-eastern Karnataka in peninsular India. The general vegetation of the district is that of tropical dry deciduous forests and tropical thorn forest types (Champion \& Seth 1968). The district was formerly known for its vast gold mines. The general topography is hilly, with hills (958-1120 m) made up of large boulders, interspersed with agriculture fields, scrub jungles and low granitic hills. Caves and cave systems are present among the boulder hills and subterranean caves in the low hills.

\section{Surveys}

Surveys were conducted between November and December 2013, and in May 2014 covering the entire area of Kolar District to ascertain the presence of the species. As a part of our surveys, we interviewed locals in order to locate the roost sites of bats. Several probable locations including old temples (dilapidated and occasionally used), caves, subterranean caverns and crevices among hills, and old dilapidated houses were searched intensively for bats. During our searches we found four subterranean caves on a low granite hill at Hanumanhalli, a village located $50 \mathrm{~km}$ east of Kolar township, the type locality of the Kolar Leaf-nosed Bat. Of the four subterranean caves we found one harbouring bats. At the cave as well as in the surrounding areas we conducted six mist net night surveys. At Therahalli, located $19 \mathrm{~km}$ west of Hanumanhalli, a subterranean cave was located. Here and in neighbouring boulder hills we conducted nine mist net night surveys.

\section{Specimens examined}

BNHS 18363 Hipposideros hypophyllus, Hanumanhalli, Kolar District, 04.iii.1985, Paratype, female, coll. H.R. Bhat; NHM.OU.K16.2014, Hipposideros hypophyllus, Hanumanhalli, Kolar District, 12.v.2014, male, coll. C. Srinivasulu and Aditya Srinivasulu; NHM. OU.K18.2014, Hipposideros hypophyllus, Hanumanhalli, Kolar District, 12.v.2014, male coll. Harpreet Kaur and Tariq Ahmed Shah.

Photograph: NHM.OU.PK1.2013, Hipposideros hypophyllus, Hanumanhalli, Kolar District, B. Srinivasulu and Tariq Ahmed Shah.

\section{Morphometry}

Two male individuals of the species were captured during one of the mist net night surveys at Hanumanhalli, retained as vouchers and deposited at the Natural History Museum of the Department of Zoology, Osmania University (NHM.OU.K16.2014; NHM.OU.K18.2014). External and cranio-dental measurements of the collected and preserved specimens were taken to the nearest $0.01 \mathrm{~mm}$ with the help of a digital vernier caliper. The measurements of the specimens are presented in Table 1 . The baculum of one of the male specimens (NHM.OU.K16.2014) was prepared by immersing the penis in $5 \%$ potassium hydroxide, staining with alizarin red and microdissection. This was subsequently measured using an oculometer.

\section{DNA extraction \& Molecular phylogeny}

Liver tissues were taken from freshly collected 
Table 1. External and cranio-dental measurements (in $\mathrm{mm}$ ) of voucher specimens ( $n=2$ ) of Hipposideros hypophyllus collected from Hanumanhalli, Kolar District, Karnataka.

\begin{tabular}{|c|c|c|}
\hline & $\begin{array}{c}\text { NHM. } \\
\text { ou.K16.2014 }\end{array}$ & $\begin{array}{c}\text { NHM. } \\
\text { OU.K18.2014 }\end{array}$ \\
\hline Sex & Male & Male \\
\hline \multicolumn{3}{|l|}{ External } \\
\hline Forearm length (FA) & 39.86 & 39.89 \\
\hline Head-body length (HB) & 40.88 & 41.72 \\
\hline Ear length $(E)$ & 17.72 & 16.73 \\
\hline Tail length (TI) & 24.27 & 23.30 \\
\hline Length of hindfoot $(\mathrm{Hf})$ & 6.88 & 6.69 \\
\hline Length of tibia (Tib) & 16.78 & 17.54 \\
\hline Length of $3^{\text {rd }}$ metacarpal ( $\left.3 \mathrm{mt}\right)$ & 30.31 & 30.09 \\
\hline Length of $4^{\text {th }}$ metacarpal ( $\left.4 \mathrm{mt}\right)$ & 29.63 & 32.64 \\
\hline Length of $5^{\text {th }}$ metacarpal ( $\left.5 \mathrm{mt}\right)$ & 29.08 & 29.97 \\
\hline $1^{\text {st }}$ phalanx of $3^{\text {rd }}$ metacarpal ( $\left.1 \mathrm{ph} 3 \mathrm{mt}\right)$ & 15.55 & 16.17 \\
\hline $2^{\text {nd }}$ phalanx of $3^{\text {rd }}$ metacarpal ( $\left.2 \mathrm{ph} 3 \mathrm{mt}\right)$ & 15.21 & 15.33 \\
\hline $1^{\text {st }}$ phalanx of $4^{\text {th }}$ metacarpal ( $\left.1 \mathrm{ph} 4 \mathrm{mt}\right)$ & 9.23 & 10.26 \\
\hline $2^{\text {nd }}$ phalanx of $4^{\text {th }}$ metacarpal ( $\left.2 \mathrm{ph} 4 \mathrm{mt}\right)$ & 7.22 & 8.16 \\
\hline Width of horseshoe & 5.77 & 5.46 \\
\hline \multicolumn{3}{|l|}{ Cranio-dental } \\
\hline Greatest length of the skull (GTL) & 17.21 & 17.37 \\
\hline Condylocanine length (CCL) & 14.56 & 14.92 \\
\hline Condylobasal length $(\mathrm{CBL})$ & 14.88 & 15.26 \\
\hline Zygomatic breadth (ZB) & 8.13 & 8.1 \\
\hline Breadth of braincase (BB) & 7.78 & 7.93 \\
\hline Mandible length (M) & 10.04 & 10.0 \\
\hline Mandibular toothrow $\left(\mathrm{CM}_{3}\right)$ & 5.85 & 5.76 \\
\hline Maxillary toothrow $\left(\mathrm{CM}^{3}\right)$ & 5.34 & 5.44 \\
\hline Posterior palatal width $\left(\mathrm{M}^{3}-\mathrm{M}^{3}\right)$ & 5.46 & 5.77 \\
\hline Anterior palatal width $\left(\mathrm{C}^{1}-\mathrm{C}^{1}\right)$ & 3.4 & 3.3 \\
\hline
\end{tabular}

specimens and used for DNA extractions. The tissue was digested at $55^{\circ} \mathrm{C}$ using an extraction buffer containing 50mMTris-Hcl, 20mMEDTA, 10\%SDS with $15 \mu$ Proteinase $K$. DNA was then extracted following salting out protocol (Miller et al. 1988) and was re-suspended in nuclease free water. A polymerase chain reaction was performed to amplify mitochondrial cytochrome oxidase subunit I (cox1) gene, using the forward primer LCO1490 (5'GGTCAACAAATCATAAAGATATTGG-3') and reverse primer HCO2198 (5'-TAAACTTCAGGGTGACCAAAAAATCA-3') (Folmer et al. 1994). PCR reactions were performed in a $25 \mu \mathrm{l}$ reaction volume wherein $12.5 \mu \mathrm{l}$ of the $2 \mathrm{X}$ PCR master mix (Thermo Scientific) was taken to which $1 \mu$ l forward primer, $1 \mu$ l reverse primer, $2 \mu$ l template DNA were added and the final volume then adjusted with nuclease free water. The PCR thermal regime consisted of one cycle of $1 \mathrm{~min}$ at $94^{\circ} \mathrm{C}$; five cycles of $1 \mathrm{~min}$ at $94^{\circ} \mathrm{C}, 1.5 \mathrm{~min}$ at $45^{\circ} \mathrm{C}$ and $1.5 \mathrm{~min}$ at $72^{\circ} \mathrm{C}$; 35 cycles of $1 \mathrm{~min}$ at $94^{\circ} \mathrm{C}, 1.5 \mathrm{~min}$ at $50^{\circ} \mathrm{C}$ and $1 \mathrm{~min}$ at $72^{\circ} \mathrm{C}$ and a final cycle of $5 \mathrm{~min}$ at $72^{\circ} \mathrm{C}$ (Hebert et al. 2003). The PCR products were then outsourced for sequencing. The BLAST tool (Altschul et al. 1990) was used to analyze the integrity of the sequence. The sequence was submitted to NCBI GenBank (accession number KM069426). We retrieved additional sequences for other related species from NCBI GeneBank database (http://www.ncbi. nlm.nih.gov/). GenBank accession numbers for the sequences used for the analysis are provided in Table 2. Species belonging to the family Vespertilionidae were used as outgroups in the analysis. Sequences were aligned using MUSCLE (Edgar 2004), and a molecular phylogenetic analysis was performed using the MEGA 6.0 (Tamura et al. 2013). A best fit model for nucleotide substitution was selected from 24 models using MEGA 6.0 (Tamura et al. 2013) based on the minimum Bayesian Information Criterion (BIC) value (Nei \& Kumar 2000). Hasegawa-Kishino-Yano (1985) model with gamma distribution and invariant sites $(\mathrm{HKY}+\mathrm{G}+\mathrm{I}, \mathrm{BIC}=4695.88$, InL $=-2047.00, G=0.12, I=0.00$ ) was obtained as a best fit model. The phylogenetic tree was constructed using a Maximum Likelihood (ML) method and its reliability was estimated using bootstrap values run for 1000 iterations.

\section{RESULTS AND DISCUSSION}

\section{Description (Image 1)}

A medium-sized bat with forearm length ranging between 39.86-39.89 mm. Comparable in size with Hipposideros durgadasi with which it shares its roost at Hanumanhalli (Kaur et al. 2014). Ears tall (16.73$17.72 \mathrm{~mm}$ ) and ear conch with 10 transverse ridges, the bottom six ridges distinctly bifurcated towards the outer border. Body colour fawn to golden to pale grey depending upon the time of the year. In winter we observed the individuals to be deep golden-coloured with fat deposits, while in summer the bats were dark grey to pale grey all over. The area surrounding the noseleaf is pigmented dark as are the ears that are dark in comparison to the rest of the body. The anterior leaf is cup-shaped with a slight median fold which curves slightly inward when viewed from the underside of the noseleaf and possesses a single wave on the lateral margin. Nostrils well-developed, the narial lappets do not cover the nostrils and are present more toward the lateral surface of the nostrils. The single well developed 
Table 2. Details of COI sequences of Hipposideros species of bicolor species group used for the phylogenetic analysis

\begin{tabular}{|c|c|c|}
\hline Species & $\begin{array}{c}\text { GenBank } \\
\text { Accession Number }\end{array}$ & Location \\
\hline Hipposideros cervinus & HM540360 & Malaysia, Johor, Kuala Jasin, Endau Rompin National Park \\
\hline Hipposideros cervinus & HM540354 & Malaysia, Sabah, Gomantong Caves \\
\hline Hipposideros cineraceus & HM540494 & Laos, Vientiane, Vang Vieng, Near Ban Nam Pe \\
\hline Hipposideros cineraceus & HM540486 & Viet Nam, Quang Ninh, Minh Hoa, Ke Bang \\
\hline Hipposideros dyacorum & HM540516 & Malaysia, Sabah, Sepilok Forest Reserve \\
\hline Hipposideros dyacorum & HM540515 & Malaysia, Kelantan, Gua Musang \\
\hline Hipposideros doriae & HM540514 & Malaysia, Pahang, Kuala Lompat \\
\hline Hipposideros khaokhouayensis & HM540535 & Laos, Vientiane, Vang Vieng, Near Ban Nam Pe \\
\hline Hipposideros khaokhouayensis & HM540534 & Laos, Vientiane, Vang Vieng, Near Ban Nam Pe \\
\hline Hipposideros halophyllus & HM540531 & Malaysia, Perlis, Kg. Bukit Jerneh \\
\hline Hipposideros galeritus & HM914937 & Viet Nam, Dong Nai, Tan Phu District, Cat Tien National Park \\
\hline Hipposideros galeritus & HM540530 & Laos, Champasak, Nong, Approx 5 km W of km20, Dong Kanthung \\
\hline Hipposideros pomona & HM540555 & Myanmar \\
\hline Hipposideros pomona & HM540607 & Laos, Champasak, $5 \mathrm{kmW}$ Of 'Kilometre 20', Dong Kanthung Region \\
\hline Hipposideros rotalis & HM540616 & Laos, Vientiane, Vang Vieng, Near Ban Nathao \\
\hline Hipposideros rotalis & HM540614 & Laos, Vientiane, Phou Khao Khouay - Tak Leuk \\
\hline Hipposideros ridleyi & HM540613 & Malaysia, Pahang, Kuala Lompat \\
\hline Hipposideros ridleyi & HM540612 & Malaysia, Pahang, Kuala Lompat \\
\hline Hipposideros ruber & JF444162 & Cote d'Ivoire, Parc National De Mont Peko, 6 km W Of Sibabli \\
\hline Hipposideros ruber & JF444152 & Cote d'Ivoire, Parc National De Mont Peko, 6 km W Of Sibabli \\
\hline Hipposideros caffer & JF444149 & Cote d'Ivoire, Parc National De Mont Peko, 6 km W Of Sibabli \\
\hline Hipposideros beatus & JF444148 & Cote d'Ivoire, Parc National De Mont Peko, 6 km W Of Sibabli \\
\hline Hipposideros beatus & JF443884 & Cote d'Ivoire, Parc National De Tai, Institute D'Ecologie Tropicale \\
\hline Hipposideros bicolor $131 \mathrm{KHz}$ & HM540340 & Malaysia, Negeri Sembilan, Pasoh Forest Reserve \\
\hline Hipposideros bicolor $131 \mathrm{KHz}$ & HM540338 & Malaysia, Pahang, Krau Wildlife Reserve \\
\hline Hipposideros bicolor $142 \mathrm{KHz}$ & HM540380 & Malaysia, Negeri Sembilan, Pasoh Forest Reserve \\
\hline Hipposideros bicolor $142 \mathrm{KHz}$ & HM540378 & Malaysia, Pahang, Krau Wildlife Reserve \\
\hline Hipposideros cf. ater & HM540368 & Indonesia, Jawa Barat, Cibodas \\
\hline Hipposideros cf. ater & HM540367 & Malaysia, Sabah, Tabin Wildlife Reserve \\
\hline Pipistrellus javanicus & HM914966 & Viet Nam, TP Ho Chi Minh, Thanh Da \\
\hline Pipistrellus coromandra & GU684804 & Viet Nam, Lam Dong, Lac Duong Dist., Bi Doup-Nui Ba national park \\
\hline
\end{tabular}

pair of supplementary leaflets start from underneath the anterior leaf extending beyond the anterior leaf, narrow and end on the upperlip. A small frontal sac is present behind the posterior leaf. Internarial septum broad at the base and tapering proximally. Intermediate noseleaf with two pairs of vibrissae (one pair of vibrissae reported by Kock \& Bhat 1994) on the lateral surface and exhibits a slight bulge in the front. The intermediate leaf is much smaller than the anterior and posterior leaves. Posterior noseleaf broader than the anterior noseleaf, short with three vertical septa dividing it into four cells the lateral ones narrower than the central pair. Wings are attached to the ankles. The last vertebra of the tail extends beyond the tail membrane.

The first upper premolar $\left(\mathrm{pm}^{2}\right)$ is minute in comparison to the second upper premolar $\left(\mathrm{pm}^{4}\right)$, in the toothrow due to which the canine and the second upper premolar are separated by a gap. The last upper molar $\left(\mathrm{m}^{3}\right)$ is reduced in comparison to the second upper molar $\left(\mathrm{m}^{2}\right)$. The first lower premolar $\left(\mathrm{pm}_{2}\right)$ is almost $2 / 3^{\text {rd }}$ the height of the second lower premolar $\left(\mathrm{pm}_{4}\right)$. The zygoma are slender and the sagittal crest is not very prominent in frontal region, absent posteriorly (Image 2).

The baculum (Image 3), broader at the base and 


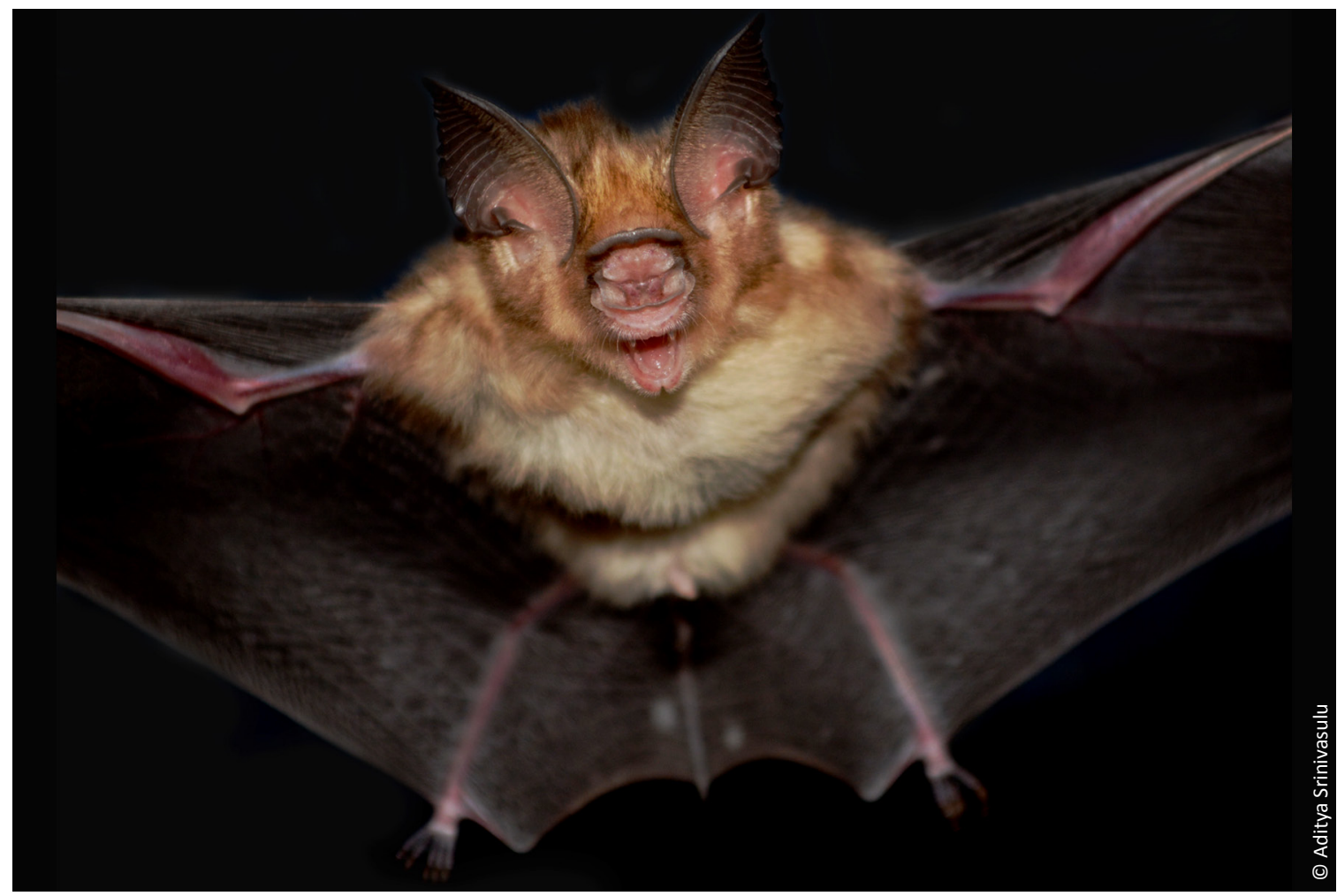

Image 1. Kolar Leaf-nosed Bat Hipposideros hypophyllus Kock \& Bhat 1994, not collected, live male specimen at type locality, Hanumanhalli, Kolar District, Karnataka, India.

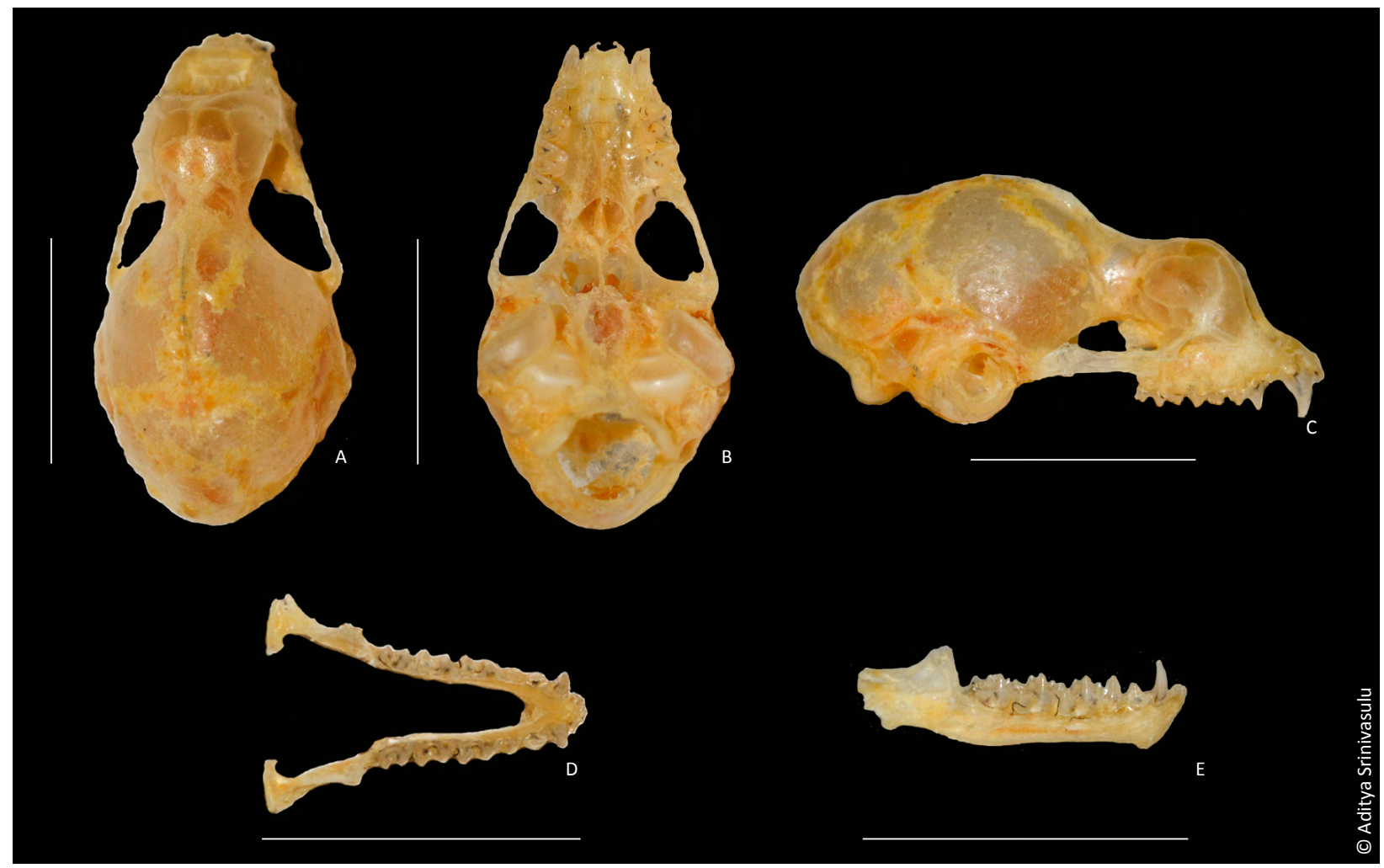

Image 2. Skull and mandible of Hipposideros hypophyllus (NHM.OU.K16.2014)

A - skull dorsal view; B - skull occlusal view; C - skull lateral view; D - mandible occlusal view; E - mandible lateral view. (Scale 10mm) 


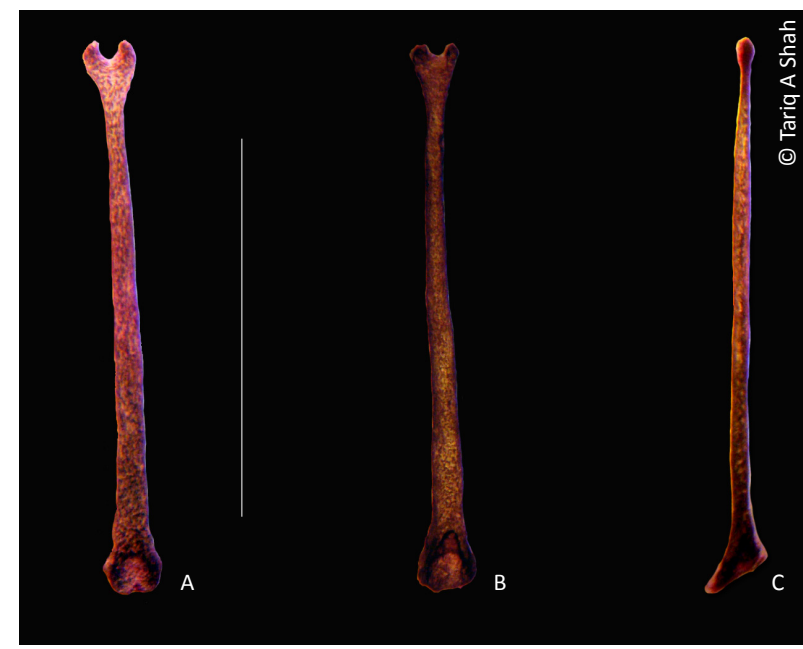

Image 3. Baculum of Hipposideros hypophyllus (NHM.OU.K16.2014) A - dorsal view; B - ventral view; C - lateral view (Scale $2 \mathrm{~mm}$ )

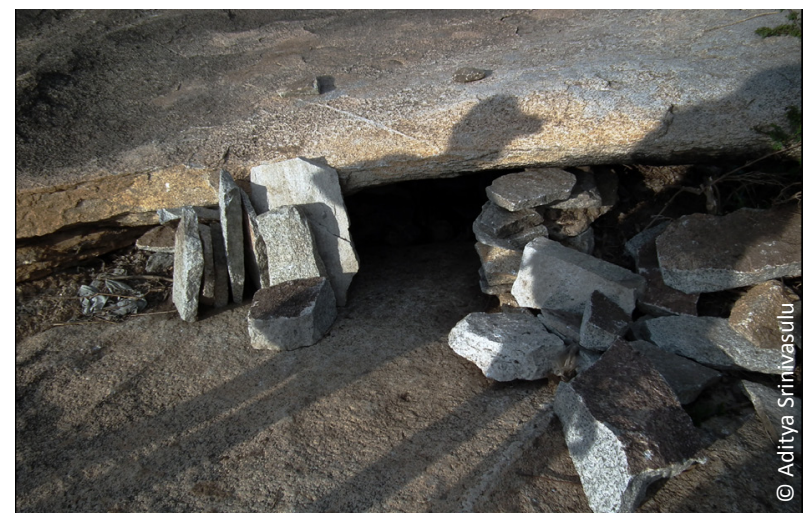

Image 4. The mouth of the subterranean cave at Hanumanhalli-the only known roost of Hipposideros hypophyllus.

gradually tapering towards the bifid apex, is straightsided and $2.5 \mathrm{~mm}$ long. Ventrally, the base possesses a concavity.

\section{Distribution}

The Kolar Leaf-nosed Bat is endemic to Karnataka, India and has been known from two localities, namely, Hanumanhalli and Therahalli in Kolar District (Kock \& Bhat 1994; Molur \& Srinivasulu 2008). Presently based upon mist net night surveys and collections in both areas, we found that this species is conspicuously absent from Therahalli and is restricted to a single subterranean cave in Hanumanhalli, the type locality.

\section{Population estimates}

We roughly estimate the population of Hipposideros hypophyllus to be between 150-200 individuals in Hanumanhalli, based on counts of emerging bat
Table 3. Bat species netted and released during mist net night surveys in Hanumanhalli and Therahalli, Kolar District, Karnataka

\begin{tabular}{|c|c|c|c|c|}
\hline \multicolumn{2}{|c|}{ Survey Time } & Nov 2013 & Dec 2013 & May 2014 \\
\hline \multicolumn{2}{|c|}{ No. of mist net night surveys } & 2 & 1 & 3 \\
\hline \multicolumn{5}{|c|}{ Hanumanhalli (no. of individuals netted) } \\
\hline 1. & Hipposideros speoris & 6 & 1 & 6 \\
\hline 2. & Hipposideros fulvus & 4 & 0 & 2 \\
\hline 3. & Hipposideros hypophyllus & 4 & 0 & 4 \\
\hline 4. & Hipposideros durgadasi & 2 & 2 & 8 \\
\hline 5. & Rhinopoma hardwickii & & & 1 \\
\hline \multicolumn{5}{|c|}{ Therahalli (no. of individuals netted) } \\
\hline \multicolumn{2}{|c|}{ No. of mist net night surveys } & 4 & 2 & 3 \\
\hline 1. & Hipposideros durgadasi & 0 & 0 & 4 \\
\hline
\end{tabular}

Table 4. Emergence times of bat species from Hanumanhalli and Therahalli, Kolar District, Karnataka

\begin{tabular}{|l|l|c|}
\hline & Species & $\begin{array}{c}\text { Emergence time } \\
\text { (in hr) }\end{array}$ \\
\hline \multicolumn{2}{|l|}{ Hanumanhalli (12.v.2014) } \\
\hline 1. & Hipposideros speoris & 1816 \\
\hline 2. & Hipposideros fulvus & 1837 \\
\hline 3. & Hipposideros hypophyllus & 1848 \\
\hline 4. & Hipposideros durgadasi & 1855 \\
\hline 5. & Rhinopoma hardwickii & 1853 \\
\hline Therahalli (13.v.2014) & 1859 \\
\hline 1. & Hipposideros durgadasi & \\
\hline
\end{tabular}

numbers, and extrapolating a ratio of individuals mistnetted at the cave entrance (Table 3). During our surveys we found the species to be restricted to the type locality and it has most probably become locally extinct in Therahalli.

\section{Habitat and ecology}

We found Hipposideros hypophyllus roosting in inaccessible narrow subterranean granite caves (Image 4). It shared its roost with $H$. speoris, $H$. fulvus (cohabitants reported earlier, present observation), $H$. durgadasi (see Kaur et al. 2014); earlier reported as $H$. cineraceus see Bhat \& Jacob 1990; Kock \& Bhat 1994), and Rhinopoma hardwickii (present observation). Each species of bat had its own time of emergence (Table 4) and were found to forage in the vicinity of the roosting site. Surveys carried out in the winter months showed that the bats foraged less and very few individuals of all the four species of hipposiderids emerged from their 
roost for foraging leading to the assumption that bats here enter torpor during this period corroborated by our observations on bats in neighbouring districts. We observed pregnant and lactating females during the late summer surveys, thus we did not collect any females.

\section{Phylogenetic position}

The Model test suggested that the best fit nucleotide substitution model was the Hasegawa-Kishino-Yano (1985) model with gamma distribution and invariant sites $(\mathrm{HKY}+\mathrm{G}+\mathrm{I}, \mathrm{BIC}=4695.88, \mathrm{InL}=-2047.00, \mathrm{G}=0.12$, $\mathrm{I}=0.00$ ). The resultant Maximum Likelihood (ML) tree shows Hipposideros hypophyllus nested within the clade of galeritus subgroup of bicolor species group (Fig. 1). This is corroborated by the morphological characters of the species which differs from individuals of the bicolor subgroup in possessing supplementary leaflets, a broad, short skull with an elevated rostral profile, and karyologically in possessing intercalary C-bands in two of the submetacentric autosomal pairs in addition to the pericentric bands (Sreepada et al. 1993; Kock \& Bhat 1994). Additionally, our results concur with recent phylogenetic analysis of hipposiderids of Southeast Asia that shows $H$. galeritus and $H$. cervinus form a clade of galeritus subgroup separate from the clade of bicolor subgroup (Murray et al. 2012).

\section{Threats and conservation}

The hill on which the subterranean cave roost is located is granitic in nature. Here and in adjoining areas illegal granite stone extraction is occurring (Image 5). On the same hill we came across two more roosting sites in subterranean caverns that were abandoned two years ago by bats due to fires lit for easier extraction of the stone. The mining activity has perilously progressed to within 50-60 $\mathrm{m}$ from the only known roost of the Kolar Leaf-nosed Bat. Based on updated information on the distribution and threats (this paper) we propose a new conservation status of the species (Appendix 1). We also propose that urgent steps to mitigate habitat degradation is initiated.

\section{REFERENCES}

Altschul, S.F., W. Gish, W. Miller, E.W. Myers \& D.J. Lipman (1990). Basic local alignment search tool. Journal of Molecular Biology 215(3): 403-410; http://dx.doi.org/10.1016/S0022-2836(05)803602

Banerjee, K., H.R. Bhat, G. Geevargheese, P.G. Jacob \& A.S. Malunjkar (1988). Antibodies against Japanese encephalitis virus in insectivorous bats from Karnataka. Indian Journal of Medical Research 87: 527-530.

Bhat, H.R. \& P.G. Jacob (1990). Bio-ecology of Hipposideros cineraceus Blyth, 1853 (Chiroptera, Rhinolophidae) in Kolar District, Karnataka, India. Mammalia 54(2): 182-188.

Champion, H.G. \& S.K. Seth (1968). Revised Survey of The Forest Types of India. Manager of Publications, New Delhi, 404pp.

Edgar, R.C. (2004). MUSCLE: multiple sequence alignment with high accuracy and high throughput. Nucleic Acids Research 32: 17921797; http://dx.doi.org/10.1093/nar/gkh340

Folmer, O., M. Black, W. Hoeh, R. Lutz \& R. Vrijenhoek (1994). DNA primers for amplification of mitochondrial cytochrome c oxidase subunit I from diverse metazoan invertebrates. Molecular Marine Biology and Biotechnology 3: 294-299.

Hasegawa, M., H. Kishino \& T. Yano (1985). Dating the human-ape split by a molecular clock of mitochondrial DNA. Journal of Molecular Evolution 22: 160-174.

Hebert, P.D.N., A. Cywinska, S.L. Ball \& J.R. deWaard (2003). Biological identifications through DNA barcodes. Proceedings of the Royal Society of London, Series B - Biological Science 270: 313-321.

Kaur, H., C. Srinivasulu, B. Srinivasulu, T.A. Shah, G. Devender \& A.

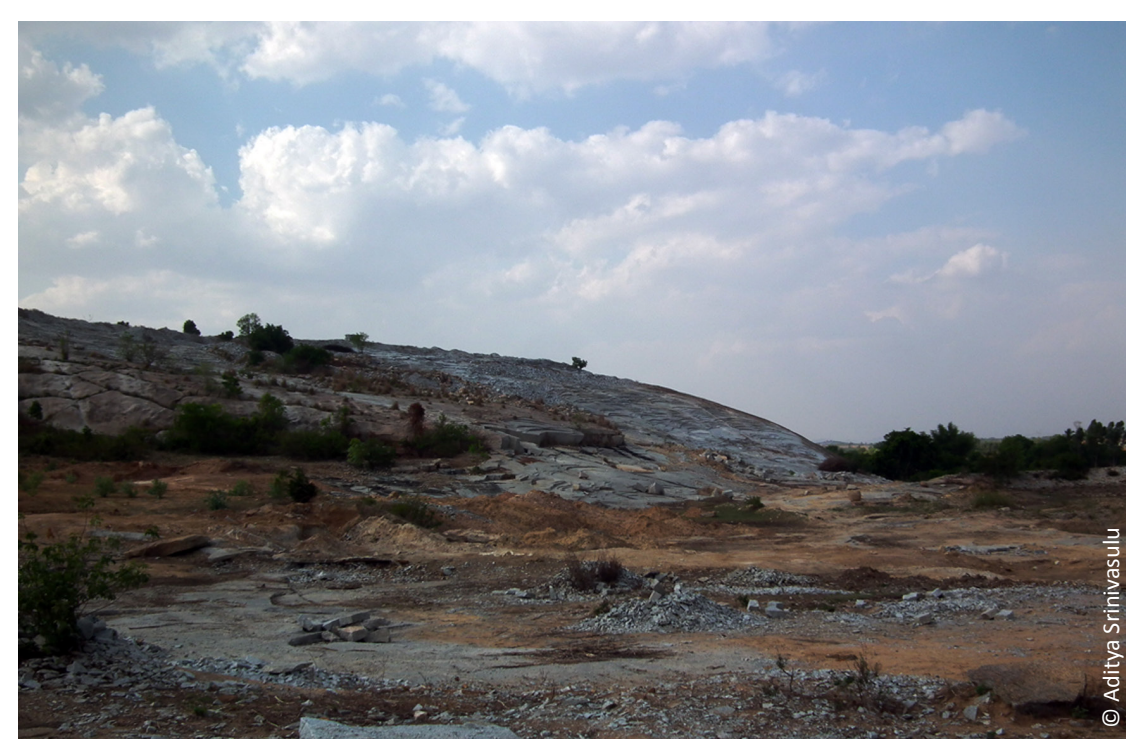

Image 5. View of the habitat on the granitic hill at Hanumanhalli, Kolar District, Karnataka, India showing habitat destruction due to stone quarrying. 


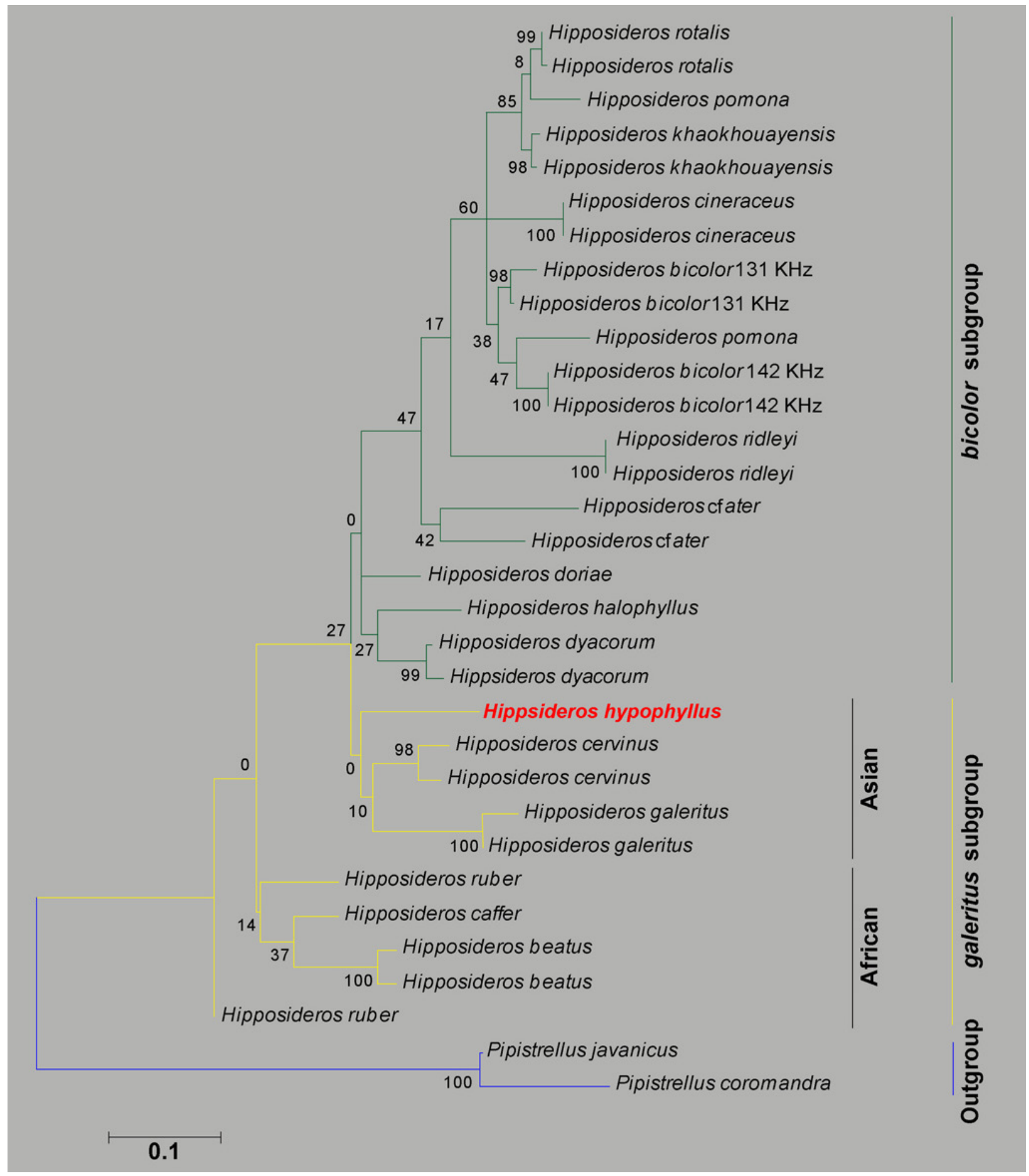

Figure 1. Phylogenetic position of Hipposideros hypophyllus inferred using the Maximum Likelihood (ML) method employing the HKY+G+I model. Bootstrap values were calculated from 1000 bootstrap iterations, values are shown to the left of each node. Members of Pipistrellus species are used as the outgroup.

Srinivasulu (2014). Taxonomic notes and distribution extension of Durga Das's Leaf-nosed Bat Hipposideros durgadasi Khajuria, 1970 (Chiroptera: Hipposideridae) from south India. Biodiversity Data Journal 2: e4127; http://dx.doi.org/10.3897/BDJ.2.e4127

Kock, D. \& H.R. Bhat (1994). Hipposideros hypophyllus n. sp. of the H. bicolor-group from peninsular India. Senckenbergiana 73(1-2)
25-31.

Miller, S.A., Dykes, D.D. \& H.F. Polesky (1988). A simple salting out procedure for extracting DNA from human nucleated cells. Nucleic Acids Research 16(3): 1215.

Molur, S. \& C. Srinivasulu (2008). Hipposideros hypophyllus. The IUCN Red List of Threatened Species. Version 2014.2. <www.iucnredlist. 
Appendix 1. Proposed Red List Status for Hipposideros hypophyllus

Current Status: Endangered B1ab(iii)+2ab(iii)

Proposed Status: Critically Endangered B1ab(iii)+2ab(iii)

Taxonomy

Scientific name: Hipposideros hypophyllus

Species authority: Kock \& Bhat, 1994

Common names: Kolar Leaf-nosed Bat

Synonyms: Hipposideros pomona (in part)

Taxonomic notes: Belongs to galeritus subgroup of bicolor species group.

\section{Geographic range}

Range description: Endemic to India, Karnataka, Kolar District. The estimated (approximate) current extent of occurrence (EOO) is less than $100 \mathrm{~km}^{2}$ and the known area of occupancy (AOO) is less than $10 \mathrm{~km}^{2}$.

Countries: India (state of Karnataka)

\section{Habitat and Ecology}

Habitat and Ecology: Known to inhabit narrow, inaccessible subterranean cave and sharing its roost with other species of bats namely Hipposideros durgadasi, Hipposideros speoris, Hipposideros fulvus and Rhinopoma hardwickii.

\section{Threats}

Major Threats: On-going illegal granite mining and stone quarrying occur perilously close to the roost at the type locality thereby altering the quality and nature of the habitat. Unknown threats, most probably habitat alteration and human use have resulted in the extirpation of the species from Therahalli and also other subterranean caverns in the type locality.

Population

Population: No information on the population status. The estimated number of individuals in the only known roost is between $150-200$ individuals.

Population trend: Declining, inferred from the non-availability of the species in other similar habitats where the species previously occurred.

\section{Conservation}

Conservation action: No conservation actions are currently in place. There is an urgent need to prohibit stone quarrying adjacent to the only known roosting site of this species. Education and awareness programs need to be carried out among the general public and also among the decision makers, for the protection of this species. Immediate action needs to be taken by according protected status to Hipposideros hypophyllus under the Indian Wildlife (Protection) Act.

\section{Assessment Information}

Red List category and criteria: Critically Endangered B1ab(iii)+2ab(iii)

Justification: Hipposideros hypophyllus is assessed as Critically Endangered because it is restricted in distribution to only one subterranean cave at the type locality Hanumanhalli, and an estimated area of occupancy (AOO) of less than $10 \mathrm{~km}^{2}$. There is also a continuing decline in the quality of its habitat and threat to its roost due to illegal granite mining.

org>. Downloaded on 02 August 2014.

Murray, S.W., P. Campbell, T. Kingston, A. Zubaid, C.M. Francis \& T.H. Kunz (2012). Molecular phylogeny of hipposiderid bats from Southeast Asia and evidence of cryptic diversity. Molecular Biology and Evolution 62: 597-611.

Nei, M. \& S. Kumar (2000). Molecular Evolution and Phylogenetics. Oxford University Press, New York, 333pp.

Sreepada, K.S., K.N. Naidu \& M.E. Gururaj (1993). Trends of karyotypic evolution in the genus Hipposideros (Chiroptera: Mammalia). Cytobios 75: 49-57.

Srinivasulu, C. \& B. Srinivasulu (2012). South Asian Mammals, Their Diversity, Distribution and Status. Springer, New York, xii+467pp.

Tamura, K., G. Stecher, D. Peterson, A. Filipski \& S. Kumar (2013). MEGA6: Molecular Evolutionary Genetics Analysis Version 6.0. Molecular Biology and Evolution 30(12): 2725-2729; http:// dx.doi.org/10.1093/molbev/mst197
Author Details: BHARGAVI SRINIVASULU is interested in molecular phylogenetics, taxonomy and biogeography of endemic bats of peninsular India. CHELMALA SRINIVASULU who heads the Wildlife Biology and Taxonomy Lab at Department of Zoology is working on molecular phylogenetics, taxonomy, ecology and biogeography of tetrapods of South Asia. HARPREET KAUR is a doctoral student working on the taxonomy and molecular phylogeny of endemic hipposiderids of India. TARIQ A. SHAH and G. DEVENDER are project fellows in DST-SERB project and working on documenting distribution and studying taxonomy of insectivorous bats of peninsular India. ADITYA SRINIVASULU is a student researcher interested in studying nature, molecular phylogenetics and photography.

Author Contribution: All authors contributed equally in field work. BS studied the paratype. HK, TAS, GD worked on the fresh voucher specimens, HK and BS extracted and sequenced the gene, CS and AS performed the molecular analysis. $\mathrm{BS}$ and CS designed and wrote the paper.

Acknowledgements: We are thankful to the Mr. Vinay Luthra, IFS, Principal Chief Conservator of Forests (WL) and Chief Wildlife Warden, Karnataka Forest Department for study and collection permits; the DCF and other staff of Kolar division, Karnataka Forest Department for their cooperation during the survey. We also thank Asad Rahmani, Director; Deepak Apte, COO; Rahul Khot, Curator, Natural History Collection department and Dr. Bandana Aul Arora, Mammalogist, for their help during study of the museum specimens in Bombay Natural History Society (BNHS), Mumbai. We thank the Head, Department of Zoology, Osmania University for necessary facilities. 